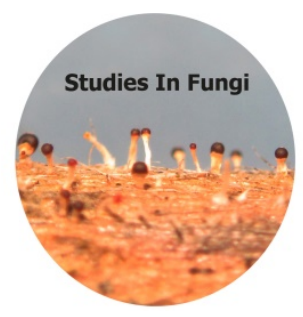

\title{
Article
}

Doi 10.5943/sif/5/1/1

\section{Inocybe cavalcantiae, a new species from northern Brazil}

\section{Wartchow F}

Universidade Federal da Paraíba, Departamento de Sistemática e Ecologia, João Pessoa, PB, Brazil ORCID: 0000-0003-4930-565X

Wartchow F 2020 - Inocybe cavalcantiae (Inocybaceae), a new species from northern Brazil. Studies in Fungi 5(1), 1-5, Doi 10.5943/sif/5/1/1

This article is dedicated to my beloved ex-advisor Prof. Maria Auxiliadora de Queiroz Cavalcanti, in occasion to her $90^{\text {th }}$ Birthday.

\begin{abstract}
Inocybe cavalcantiae is described based on morphological data from Pernambuco, Northeast Brazil. It is characterized by radially fibrillose/rimose pileus, narrow marginate bulb, nodulose basidiospores, lageniform to clavate metuloids pleurocystidia and versiform metuloids caulocystidia. The species is described, illustrated and compared with morphologically similar species.
\end{abstract}

Key words - Agaricales - Agaricomycetes - Basidiomycota - Neotropic - taxonomy

\section{Introduction}

Inocybe (Fr.) Fr. sensu stricto (=Inocybe clade) is one of the seven clades of a strongly supported monophyletic group, on which they are recognized as the distinct genera Auritella Matheny \& Bougher, Inosperma (Kühner) Matheny \& Esteve-Rav., Mallocybe (Kuyper) Matheny, Vizzini \& Esteve-Rav., Nothocybe Matheny \& K.D.P. Latha, Pseudosperma Matheny \& EsteveRav. and Tubariomyces Esteve-Rav. \& Matheny (Latha \& Manimohan 2017, Matheny \& Bougher 2017, Matheny et al. 2020). Inocybe is recognized by brownish, small to medium sized basidiomes, fibrillose to squamulose pileus, an attached lamellae and brown spore print.

This genus is infrequently inventoried in Brazil. Recent list by Wartchow \& Sá (2018) reported six well known species viz., I. austrolilacina Wartchow \& R.M. Silveira, I. curvipes P. Karst., I. hyperhytra Rick, I. lepidospara Wartchow, I. martinica Pegler and I. violaceolamellata Rick. Continuing studies on the genus Inocybe, an interesting species was collected in the Atlantic Forest from the State of Pernambuco, northeast Brazil and is herein described as new.

\section{Materials \& Methods}

The new species was collected at 'Mata do Estado', municipality of São Vicente Férrer, Perrnabuco, Brazil, in a mountain rain Atlantic Forest remnant with an altitude varying from 600 to 640 m (Ferraz \& Rodal 2006). Fresh material was collected and studied following conventional morphology based taxonomic methods. Color codes and color names follow Flora of British Fungi (1969). Basidiospore data follow Wartchow \& Sá (2018). The specimen examined is deposited in the herbarium JPB (Thiers, continuously updated). 


\section{Results}

Inocybe cavalcantiae Wartchow, sp. nov.

Figs $1-2$

MycoBank number: MB 833603

Etymology - named in honor of Prof. Maria Auxiliadora de Queiroz Cavalcanti, in occasion of her $90^{\text {th }}$ Birthday.

Diagnosis - the new species is characterized by the slender basidioma, pruinose stipe in overall length, narrow marginate bulb, basidiospores 6.8-8.2 (-8.6) × (4.5-) 5-6 (-6.4) $\mu \mathrm{m}$ with 811 nodules, wide hymenial metuloids 48-72 $\times 16-27 \mu \mathrm{m}$ and the versiform metuloids caulocystidia 36-80 × 18-28 $\mu \mathrm{m}$ spread over all stipe surface.

Holotype - Brazil, Pernambuco. São Vicente Férrer, Mata do Estado, on soil in a montane rain Atlantic Forest remnant, 10 July 2008, J.M. Baltazar \& L. Trierveiler-Pereira s.n. (JPB 63972).

Pileus ca $22 \mathrm{~mm}$, plane, plane-subconcave shallowly umbonate with a shallow papila; surface brownish (paler than "Snuff brown 17") to dark yellowish brown around papilla (darker than "Buff 17”); surface radially fibrillose-rimose, mostly near margin; margin with a more or less plicate/srimose appearance; context thin, up to $2 \mathrm{~mm}$ at center, translucid, flesh beige, unchanging. Lamellae adnexed, close, buff (slightly darker than "Buff 52", but paler than "Snuff brown 17"), $3.5 \mathrm{~mm}$ broad, lamella edge entire, concolorous, with lamellulae of diverse lengths. Stipe ca $35 \times 4$ $\mathrm{mm}$ (without bulb), central, subequal, slightly tapering upward; surface pale cream (4D), distinctly pruinose throughout; base marginate bulbous, $7 \mathrm{~mm}$ wide $6 \mathrm{~mm}$ high; context fibrous, dull white. Odour and taste not performed.

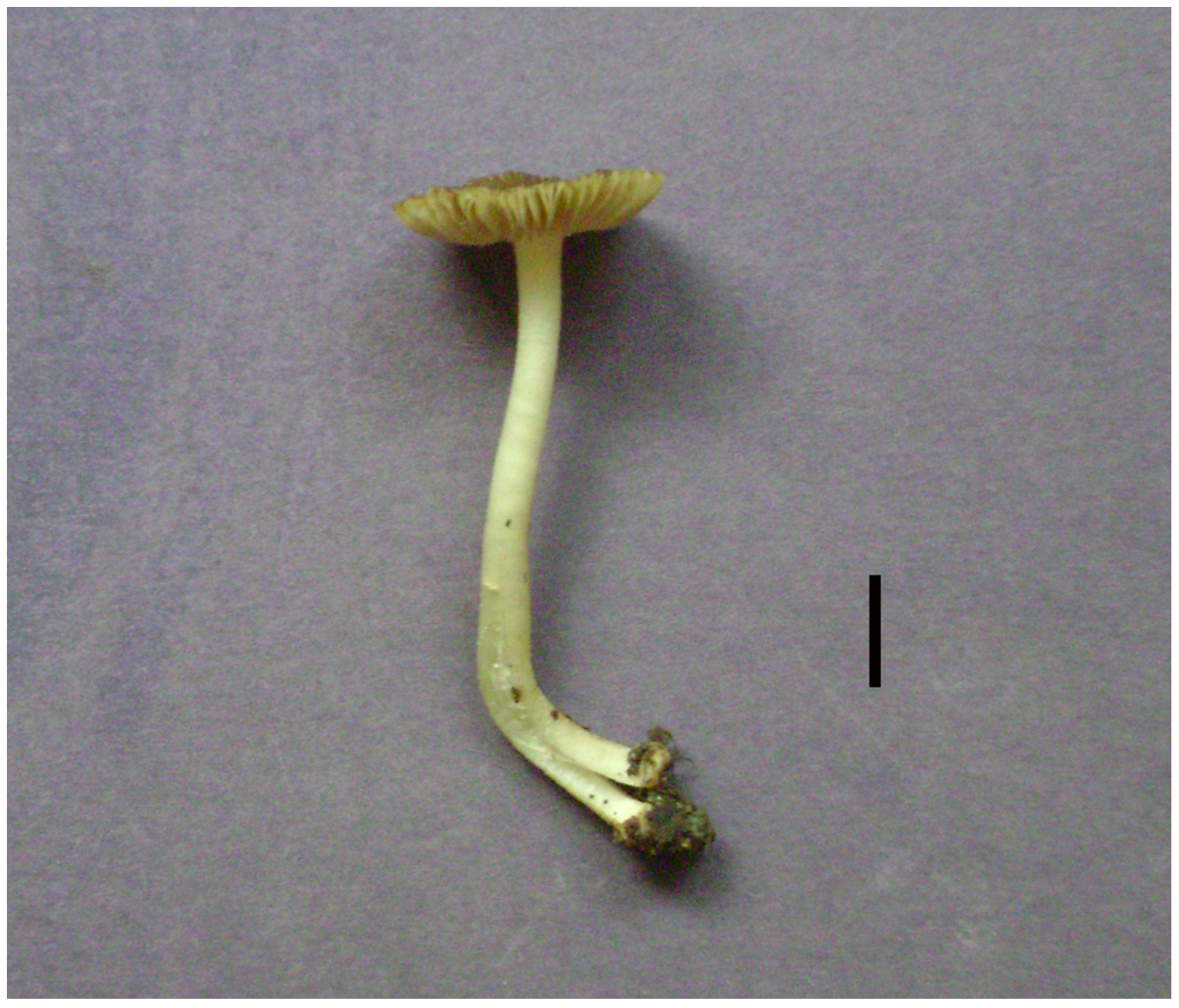

Fig. 1 - Inocybe cavalcantiae (JPB, holotype). Basidiome. Scale Bar $=10 \mathrm{~mm}$. 
Basidiospores 6.8-8.2 (-8.6) × (4.5-) 5-6 (-6.4) $\mu \mathrm{m}, \mathrm{L}=7.6 \mu \mathrm{m} ; \mathrm{W}=5.6 \mu \mathrm{m}, \mathrm{Q}=(1.20-)$ 1.24-1.49 (-1.54), Qm = 1.36, ellipsoid with suprahilar depression, with 8-11 prominent subconical to obtuse nodules. Basidia up to $20 \times 9 \mu \mathrm{m}$, clavate, four sterigmate, with basal clamp connections. Pleurocystidia 48-72 × 16-27 $\mu \mathrm{m}$, narrowly lageniform to lageniform with broadly obtuse apex then clavate to broadly clavate; metuloid, $2-3 \mu \mathrm{m}$ thick at middle portion then slightly thickening to $4 \mu \mathrm{m}$ near apex; hyaline, with crystals at apices, except in the clavate elements. Cheilocystidia similar to pleurocystidia in size and shape. Hymenial paracystidia difficult to distinguish. Lamella trama regular. Caulocystidia metuloidal, in dense fasciculate tufts over the entire stipe, 36-80 × 18$28 \mu \mathrm{m}$, versiform, i.e. ventricose, lageniform, ellipsoid to ovoid somewhat presenting an obtuse apex, uniformly thick walled up to $2 \mu \mathrm{m}$, hyaline, without or sometimes with crystals at apices. Paracaulocystidia 20-27 × 16-20 $\mu \mathrm{m}$, thin to moderately thick-walled, up to $1 \mu \mathrm{m}$ thick, mixed with the caulocystidia. Pileipellis near to pileus centre having a erect orientation turning a cutis with periclinal oriented hyphae ranging to 6-12 $\mu \mathrm{m}$ wide somewhat inflating to $21 \mu \mathrm{m}$, yellowish brown plasmatic content, strongly incrusted, thin-walled, clamp connections present.

Known distribution - known only from the type locality.

Habitat - on soil in a mountain Atlantic Forest remnant surrounded by members of Fabaceae subfam. Caesalpinoideae, Euphorbiaceae, Myrtaceae, Nyctaginaceae and Sapotaceae (Ferraz \& Rodal 2006).

Material examined - Brazil, Pernambuco. São Vicente Férrer, Mata do Estado, on soil in a montane rain Atlantic Forest remnant, 10 July 2008, J.M. Baltazar \& L. Trierveiler-Pereira s.n. (JPB 63972, holotype).

\section{Discussion}

Inocybe cavalcantiae is characterized by the slender basidioma, pruinose stipe in overall length, narrow marginate bulb, basidiospores 6.8-8.2 (-8.6) × (4.5-) 5-6 (-6.4) $\mu$ mith 8-11 nodules, wide hymenial metuloids 48-72 $\times 16-27 \mu \mathrm{m}$ and the versiform metuloids caulocystidia measuring 36-80 × 18-28 $\mu \mathrm{m}$ spread over all stipe surface.

Matheny \& Bougher (2017) presented a comprehensive key for Australian emphasizing some key characters that can be used for comparison among species. One of these species, I. dewrangia Grgur., shares many characteristics with I. cavalcantiae: the agaricoid basidiome, nodulose basidiospores, hyaline cystidia, pruinose stipe at overall length, brownish and dry pileus, stipe base with marginate bulb, pileus lacking brown streaks, brownish yellow pileus, pleurocystidia walls 2$3 \mu \mathrm{m}$ thick and stipe with about $4 \mathrm{~mm}$ wide. However, the more rimose pileus surface, the larger and more elongate basidiospores 8-10 $\times 5.5-6.5 \mu \mathrm{m}, \mathrm{L}=9 \mu \mathrm{m}$; $\mathrm{W}=5.9 \mu \mathrm{m}, \mathrm{Q}=1.36-1.74, \mathrm{Qm}=$ 1.53 with small nodules, the fusiform to utriform metuloids and occurrence under Eucalyptus L'Hér., Corymbia K.D. Hill \& L.A.S. Johnson (Myrtaceae) and/or Gastrolobium R. Br. (Fabaceae subfam. Faboidae) segregate the Australian entity from the Brazilian new species (Grgurinovic 1997, Matheny \& Bougher 2017).

Among Central and South American taxa, some of them also present marginate stipe bulb and have a distribution in the Neotropic, as for example, I. marginata Matheny, Aime \& T.W. Henkel from Guyana, I. matrisdei Singer from the Bolivian Amazon, and I. xerophytica Pegler from Guadeloupe. They differ in the following features: I. xerophytica differs in the light buff to more brownish, innately fibrillose striate to glabrous pileus surface, larger basidiospores 8-10.5 $\times 5.5$ $7.5 \mu \mathrm{m}, \mathbf{L}=9.5 \mu \mathrm{m} ; \mathbf{W}=6.5 \mu \mathrm{m}, \mathbf{Q}=(1.20-) 1.24-1.49(-1.54), \mathbf{Q}=1.47$ and narrower pleurocystidia 45-55 × 12-14 $\mu \mathrm{m}$ (Pegler 1983); I. matrisdei differs in the reddish-grayish brown to tawny pileus, larger basidiospores 7.5-8.5-9.0 (-10.0) $\pm 0.60 \times(6.0-)$ 6.5.5-7.0-7.5 (-8.0) \pm $0.47 \mu \mathrm{m}, \mathrm{Q}=(1.06-)$ 1.13-1.20-1.33 (1.42) \pm 0.01 coarsely nodulose with 11-13 nodules and smooth repent pileipellis hyphae (Singer 1961, Singer et al. 1983, Matheny et al. 2012); I. marginata differs from Pernambucan entity in the tan-caramel to pale tan with pinkish tints at pileus, pale with sordid salmon-pink tint then clay color lamellae and very broadly fusiform, occasionally lageniform, often with a short neck metuloids (Matheny et al. 2012). 
Inocybe rhodella Matheny, Aime \& M.F. Sm. from the Guiana Shield, although the bulbous stipe, differs primarily in the non-marginate instead marginate bulb. In addition, the pale red then pinkish gray lamellae after pileus expansion, shorter basidiospores (6.0-) 6.5-6.8-7 (-7.5) $\pm 0.4 \times$ (5-) 5.5-5.7-6 $\pm 0.3 \mu \mathrm{m}, \mathrm{Q}=1.08-1.20-1.27 \pm 0.06$ and mostly lageniform sometimes subfusiform to subcylindric and narrower metuloids 53-67 × 14-19 $\mu \mathrm{m}$ also are distinct features for I. rhodella (Matheny et al. 2012).

Thus, based on the set of characteristics described above, I conclude that $I$. cavalcantiae is a new species among species of Inocybe.

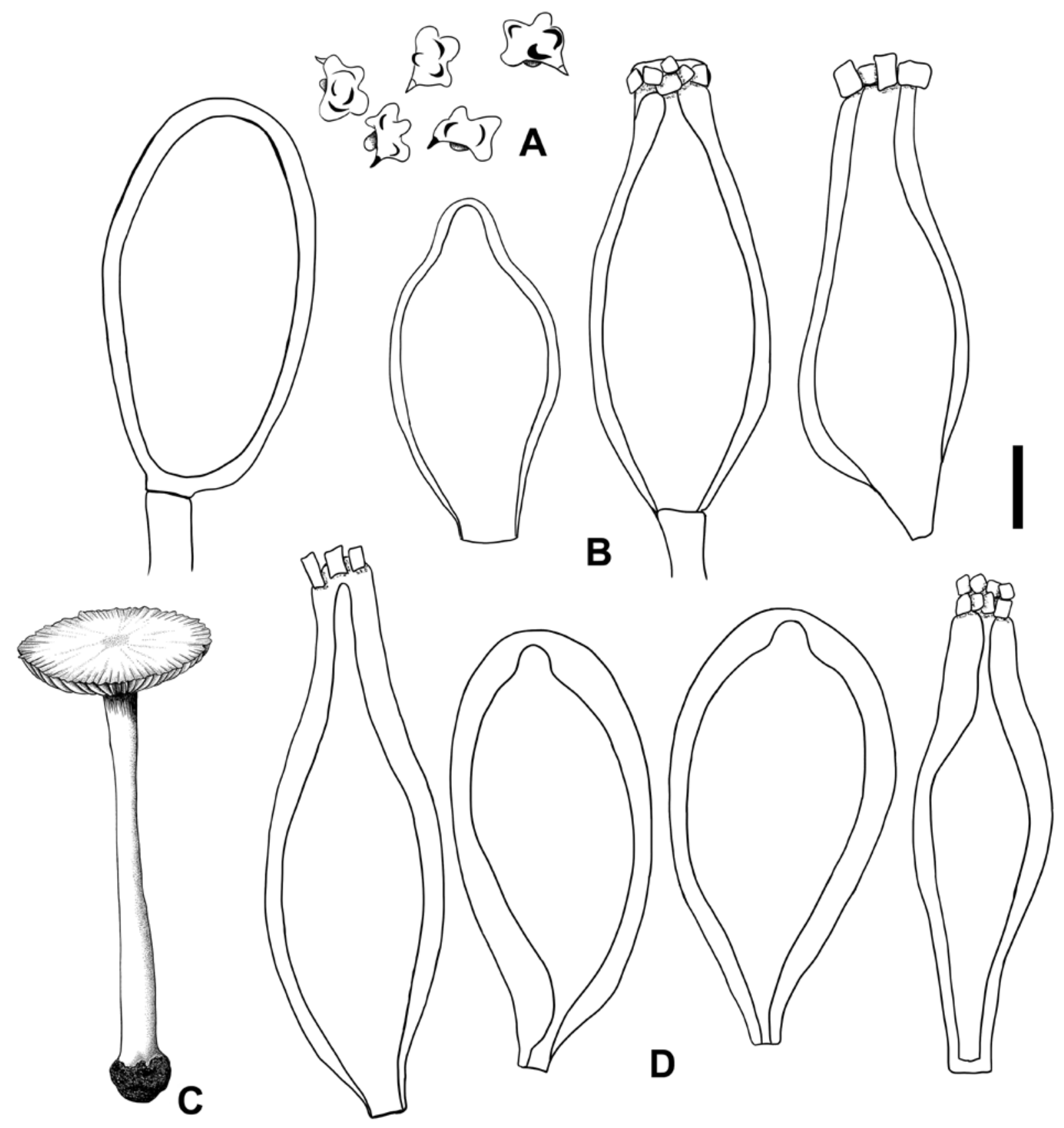

Fig. 2 - Inocybe cavalcantiae (JPB, holotype). A Basidiospores. B Caulocystidia. C Pleurocystidia. Scale bar $=10 \mu \mathrm{m}$.

\section{Acknowledgements}

I wish thank FACEPE for Post-doctoral grant (BFP BFP 0100-2.03/09), and 'Conselho Nacional de Desenvolvimento Científico e Tecnológico' (CNPq) by funding the project 'Fungos 
agaricoides em áreas de Mata Atlântica e Caatinga no Estado da Paraíba' (Edital Universal Proc. 420.448/2016-0) and providing 'Produtividade em Pesquisa' (Proc. 307922/2014-6 and Proc. 307947/2017-3) grant. Victor R. M. Coimbra, Juliano M. Baltazar and Larissa Trierveiler-Pereira are acknowledged by the material collection.

\section{References}

Ferraz EMN, Rodal MJN. 2006 - Caracterização fisionômico-estrutural de um remanescente de floresta ombrófila Montana de Pernambuco, Brasil. Acta Botanica Brasilica 20, 911-926.

Grgurinovic CA. 1997 - Larger Fungi of South Australia. The Botanic Garden of Adelaide and State Herbarium and the Flora and Fauna of South Australia Handbooks Comitee, Adelaide.

Latha KPD, Manimohan P. 2017 - Inocybes of Kerala. SporePrint Books, Calicut.

Matheny PB, Bougher NL. 2017 - Fungi of Australia: Inocybaceae. CSIRO Publishing, Melbourne.

Matheny P B, Aime MC, Smith ME, Henkel TW. 2012 - New species and reports of Inocybe (Agaricales) from Guyana. Kurtziana 37, 23-39.

Matheny PB, Hobbs AM, Esteve-raventós F. 2020. Genera of Inocybaceae: new skin for the old ceremony. Mycologia 112, 83-120.

Pegler DN. 1983 - Agaric flora of Lesser Antilles. Kew Bulletin Additional Series 9, 1-668.

Flora of British Fungi. 1969 - Colour Identification Chart. Her Majesty’s Stationery Office, Edinburgh.

Singer R. 1961 - Monographs of South American Basidiomycetes especially those of the east slope of the Andes and Brazil. IV. Inocybe in Amazon region and a supplement to part I (Pluteus in South America). Sydowia 15, 112-132.

Singer R, Araujo IJA, Ivory MH. 1983 - The ectotrophically mycorrhizal fungi of the Neotropical lowlands, especially Central Amazonia. Beihefte zur Nova Hedwigia 77, 1-339.

Thiers B. [continuously updated] - Index Herbariorum: A global directory of public herbaria and associated staff. - New York Botanical Garden's Virtual Herbarium. http://sweetgum.nybg.org/ih/ (accessed 08 November 2019)

Wartchow F, Sá MCA. 2018 - Inocybe lepidosparta (Agaricales: Basidiomycota): a new species from Pernambuco, Brazil. New Zealand Journal of Botany 56, 438-443. 